Review Article

\title{
Polymer-Based Composites: An Indispensable Material for Present and Future Applications
}

\author{
Isiaka Oluwole Oladele $\mathbb{D}^{1},{ }^{1}$ Taiwo Fisayo Omotosho, ${ }^{1}$ and Adeolu Adesoji Adediran ${ }^{2}{ }^{2}$ \\ ${ }^{1}$ Department of Metallurgical and Materials Engineering, Federal University of Technology, PMB, 704, Akure, Ondo State, Nigeria \\ ${ }^{2}$ Industry, Innovation, and Infrastructures (SDGs-9 Group), Landmark University, PMB 1001, Omu-Aran, Kwara State, Nigeria
}

Correspondence should be addressed to Isiaka Oluwole Oladele; iooladele@futa.edu.ng

and Adeolu Adesoji Adediran; adediran.adeolu@lmu.edu.ng

Received 17 August 2020; Revised 5 October 2020; Accepted 8 October 2020; Published 19 October 2020

Academic Editor: Ana Beatriz Morales-Cepeda

Copyright (C) 2020 Isiaka Oluwole Oladele et al. This is an open access article distributed under the Creative Commons Attribution License, which permits unrestricted use, distribution, and reproduction in any medium, provided the original work is properly cited.

\begin{abstract}
Right from the early days, polymer materials have been discovered as being beneficial for various applications but a poor understanding of these materials greatly handicapped their usage. However, with a change in this trend, polymer materials have gradually displaced other materials in most applications. In recent times, due to improved research and knowledge, polymerbased materials are the first choice materials for several applications and are now replacing other materials rapidly. More advanced materials from polymers are being developed daily as a substitute for other materials even in areas where polymers are considered not to be suitable in the time past. More recently, polymers have replaced metals and ceramics in applications like constructions, aerospace, automobiles, and medical. It is no doubt that this trend will continue due to the inherent properties of polymers and sustainability potential. Today, most of the limitations of polymers are being taken care of in the formulation of composite materials. Besides, the adaptation to positive environmental influence is being handled by scientists and researchers. Hence, this review reveals core areas of application of polymer-based composites and the significance of these materials to the advancement of humanity.
\end{abstract}

\section{Introduction}

In a world filled with various materials right from the beginning, we have had the opportunity of seeing materials transcend different eras to what it is today. Over centuries, man has had different materials to deal with right from the Stone age, to the Bronze age, to the Iron age, to the Glass age, to the Steel age, to the Aluminum age, and currently to the Plastic (polymer) age [1]. All these changes in material ages resulted as man's environment constantly evolved creating the need for improved materials to suit the present needs and applications. A polymer which is arguably one of the best materials ever due to its unique properties has gained predominance in vast areas of application. Little wonder, it is the material of the $21^{\text {st }}$ century. For the material to adequately possess the required properties needed for top performance in diverse fields, polymers are usually reinforced with other materials to form composites. Hence, the formation of polymer matrix-based composites (PMCs) has remained one of the most efficient methods to influence the properties of polymers [2]. These polymer composites could be of two matrix forms; thermoset or thermoplastic. Although thermosetmatrix based composites are generally more common, thermoplastic-matrix based composites are gaining increased attention due to their advantages such as lower cost of manufacturing, high strength, low moisture content, no curing, reprocessing flexibility, and high-temperature resistance $[2,3]$. Polymer matrix composites can have either organic or inorganic polymer as the matrix and short or continuous fiber, particles of few millimeters to the nanometer range as the reinforcing material. The polymer matrix serves to firmly bond the fibers together, transfer loads to them, and uniformly distribute the load applied between them. While on the other hand, the fibers function as the major loadbearing component as a result of their higher strength and modulus. Based on the roles to be played by these 
constituents, the properties of the individual constituents are known before selection and merging. Together, thus, they provide a series of exceptional properties which include lightweight, high stiffness, high specific strength, good resistance to fatigue, wear and corrosion resistance, easy fabrication, economic efficiency, high design flexibility, and desirable thermal expansion characteristics $[2,4,5]$. These properties make PMCs an in-demand composite type in numerous fields such as automobile, aerospace, medical, civil, electronics, communications, sports, marine, military, energy, industry, construction, and various household item applications [6]. When compared to metal-matrix and ceramic-matrix composites, polymer matrix composites are a lot easier to fabricate due to their relatively low processing temperatures. The ever-growing need for sustainability, innovations, and energy-efficient technology propels researchers and engineers to take to the production of natural biodegradable polymer composites in place of the synthetic ones in a bid to promote sustainable development. Natural fibers from plants and animals have gained much attention because of this. Examples include hemp, cotton, jute, flax, bamboo, sisal, kenaf, rice husk, ramie, abaca, sugarcane bagasse, coconut coir, Kevlar wool, keratin wool, hair, and silk [7-13]. Advanced composites majorly of biodegradable sources are considered as a better alternative to conventional materials due to their significant enhancement in mechanical, structural, and tribological properties [8, 14-16]. Natural fibers when used as reinforcements particularly in the nanometer range have been found to drastically improve the properties of the materials such as the strength, stiffness, fracture toughness, thermal stability, electrical conductivity, and wear resistance of materials making them highly suitable for application in diverse fields like construction, automobile, biomedical, marine, aerospace, and military [17]. For example, Singha and Thakur [18] synthesized natural fibers of Hibiscus Sabdariffa with phenol-formaldehyde resin matrix to form a polymer composite to analyze the tensile strength, compressive strength, flexural strength, and wear resistance properties of the material. The results showed that the mechanical and wear resistance properties increased up to $30 \%$ with the fiber reinforcement making it suitable in the automotive and other related industries. Prabhakar et al. [15] also reported the work of Arjmandi et al. [19] who investigated the use of the natural fiber of rice husk $(\mathrm{RH})$ with different polymer matrices such as polyethylene (PE), polypropylene (PP), polyvinyl chloride (PVC), and polylactic acid (PLA) to form polymer composites. The findings proved that the use of RH in PE helped to significantly improve the mechanical properties, making it a suitable composite material for building and construction. Likewise, Thakur et al. [20] used natural cellulosic fiber to reinforce resorcinolformaldehyde. The resulting polymer composite was found to have improved mechanical and wear resistance properties thereby making it suitable for different industrial applications. Polymer biocomposites are reinforced with natural fillers like seed shells, animal fibers, and cellulose which make them to be preferred for biomedical applications due to their biocompatibility and resorbability [21]. Kevlar is an aramid fiber used as a reinforcement in polymeric organic matrix composites and is gaining increased applications due to its outstanding properties such as high tensile strength, lightweight, stiffness, and thermal stability [22]. The use of Kevlar in composites helps to develop high-performance materials and allows for resource efficiency which makes it suitable for application in various fields like chassis, brake pads, and different body parts of vehicles, combat helmets, ballistic face masks, and bulletproof vests for defense, rotor blades of helicopters, radomes, landing gear doors, and propellers in aircrafts, bicycle tyres, ropes, and cables [12, 22, 23]. In the biomedical field, keratin-based biomaterials have received increased application for wound healing, drug delivery, and tissue engineering due to their intrinsic biological properties and excellent biocompatibility. Keratin is a fibrous protein that forms the major structural constituent of hair, feather, hooves, wool, and horn. It is abundantly available as a byproduct from poultry and slaughterhouse $[13,24]$. Research interest is increasing in the use of natural fibers such as of sisal, jute, banana, coir, keratin, and cotton as reinforcements because of their lightweight, low-cost, eco-friendly, thermal, and acoustic insulating properties which makes them suitable for application in numerous industries which include consumer goods, biomedical industry, transportation industry, military, and civil structures [21].

To sustain the demand for light-weight materials for automobile applications and other commercial purposes, more research into the available polymer resources like waste plastics has been put into considerations. Recently, work was carried out to promote the use of secondary materials rather than creating new ones for the growing global demands for new materials. Besides, there is a need to intensify efforts towards identifying areas of applications suitable with the potentials embedded in derived materials [25-28]. This became necessary because of regulations in the developed nations for the inclusion of a high proportion of biodegradable materials in automobiles, aerospace, biomedical, and many other fields. In addition to the enhancement of the properties of some polymer composites, some natural fillers have also been reported to improve the mechanical properties and degradation of synthetic polymers, and this has been beneficial to the environment due to accelerated degradation $[25,29-32]$. This paper focuses extensively on the benefits of fiber-reinforced polymer composites over conventional materials for applications in various fields.

\section{Automobile Application}

The automotive industry happens to be one of the largest consumers of PMCs which is a result of cost savings and its lightweight. The mechanical properties offered by PMCs are uniquely important in the design of vehicles to meet some of its very pressing requirements which include an overall reduction in the weight of automobiles [2]. The reason for this is that vehicle weight reduction will promote fuel efficiency as well as cause a reduction in the emission of exhaust thereby reducing air pollution. It is estimated that about 250 million barrels of crude oil can be saved from a 25\% reduction in car mass, while fuel efficiency can be increased by $6 \%-8 \%$ for every $10 \%$ car weight reduction [2], [14, 33]. 
However, the passengers' safety must not be sacrificed in a bid to achieving these. This makes these three (lightweight, fuel efficiency, and passengers' safety) the most important factors to consider in the design of a vehicle [34]. Natural fiber polymer composites are the ideal materials for such applications due to their lightweight, high strength, high stiffness, design flexibility, high impact energy absorption, noise and vibration reduction, corrosion and abrasion resistance, lesser production cost, and biodegradability [33-35]. Figure 1 shows some of the numerous parts where PMCs are used in automobile manufacturing, which are door panel, bumper system, boot linen engine cover, refrigerated truck linens, connecting rod, dashboard, spoiler, seatback, pedal box system, wheel rim, fire engine, parcel shelves, chassis, and body stiffener $[2,14,34,36]$. Examples of automakers, their models, and parts where they use PMCs are listed in Table $1[35,36]$.

The use of natural fiber polymer composites (NFPC) in automobile parts still holds some shortcomings due to issues such as high moisture absorption and high flammability. This makes it very crucial to address such issues to prevent the failure of these parts while in service. Hence, they are combined with synthetic fibers through hybridization techniques to form hybrid composites that possess more superior mechanical and structural properties and are more costeffective [35]. From various researches and analysis, it is noted that the use of hybrid polymer composites in automobiles can bring about a significant reduction in weight of $20 \%$ to $40 \%$ while also having the potential to last 10 years longer than the conventional vehicles, thereby causing a new trend in materials selection for automobile application $[5,33,35]$. Recently, the use of recycled waste plastics in automobiles was investigated to arrest the pollution problems emanating from waste plastics. The research was carried out to propose the use of waste plastics in automobiles from where it was revealed that biofiller-recycled waste plastic-based composites were suitable for most automobile interiors such as door sills or the floor panel where moderate mechanical, good wear, and water resistance properties are desirable. The work presented that after reuse, the developed biocomposite will degrade easily due to aging when disposed off [25].

\section{Aerospace Application}

When it comes to the usage of advanced composites, the aerospace industry is one very big user. It is estimated that the aerospace industry consumes about $50 \%$ of the entire advanced composites production in the United States. Some of the reasons that spur the usage of these materials in the aerospace industry are similar to that of the automotive industry. Weight reduction, cost savings, and radiation shielding are at the forefront of concerns in this industry. The weight reduction is very crucial since it influences several factors such as fuel efficiency, speed, number of assembled parts, maneuverability, and increased range [5]. The lightweight of polymers provides the biggest advantages to the airspace industry which are weight reduction and fuel savings. According to Koniuszewska and Kaczmar [37], American Airlines operates a fleet of about 600 planes and could save up to 11,000 gallons of fuel per year by decreasing the weight of each aircraft only by 1 pound. Cost savings in aircraft production can be achieved by the use of fiberreinforced polymer composites in place of metal alloys, reduced tooling cost, reducing the number of assembled parts which cuts down on the cost implication that comes with joining various parts together as well as in their maintenance. Besides these, property variation due to changes in environmental conditions can be achieved in advanced PMCs $[5,37]$.

Polymer matrix reinforced with nanofillers has been researched to provide improved radiation protection abilities compared to their metal counterparts. Aluminum which has previously been serving this purpose provides lesser attenuation characteristics due to its low electron density and production of secondary particles. The shielding effectiveness of polymer composite materials is attributed to their insulating nature as well as the possibility of designing them to possess high-Z fillers that are nontoxic and provide higher X-ray protection [38]. For example, silicone rubber finds application in aircraft due to its excellent performance at various temperatures, its resistance to irradiation, chemicals, and aging as well as its unique electrical insulation properties while the nanoparticles of carbon such as graphene, carbon nanotube, and carbon black provide excellent resistance to oxidation in the air [38, 39].

Based on the unique mechanical, electrical, and tribological properties of fiber-reinforced polymer (FRP) composites, other commendable benefits that come from using them in aircraft are their design flexibility, reduced scrap, improved corrosion and fatigue resistance, increased strength and stiffness, resistance to flame and heat for interior panels, improved damage and impact tolerance, durability, reduced noise level, vibration-damping properties, and fracture resistance. These make it possible for polymer composites to be used for components such as aircraft brakes, bulkheads, window frames, rotors, brackets, fuselage, aircraft wing boxes, airframe, fittings, blades, vertical fins, food tray arms, and tail assemblies [37, 40].

Hybrid composites have also recently been adopted since research has shown that they manifest enhanced mechanical properties required for aerospace applications. By using hybrid kenaf/glass fiber reinforced polymer composites, the specific strength and rain erosion resistance of aircraft are increased while carbon fiber reinforced silicon carbide when used to produce aircraft brakes tend to endure temperature as high as $1200^{\circ} \mathrm{C}$ [14]. Hybrid FRP composites are extensively used for various components in the A-series aircraft. In the A320 aircraft, about $800 \mathrm{~kg}$ weight is saved from using FRP composites when compared to aluminum alloy usage while also finding increased percentage application in the A330, A340, and the A380 superjumbo airliner [41]. Boeing B-787 Dreamliner is manufactured using a large number of polymer composites and is considered by design as a breakthrough in the aerospace industry [37]. Likewise, in the design and manufacturing of SARAS shown in Figure 2, a 14-seater aircraft in India, the use of PMCs helped to reduce weight by almost $25 \%$ over the metal alloys counterpart. By comparing the result, the mass of the metal alloys was 


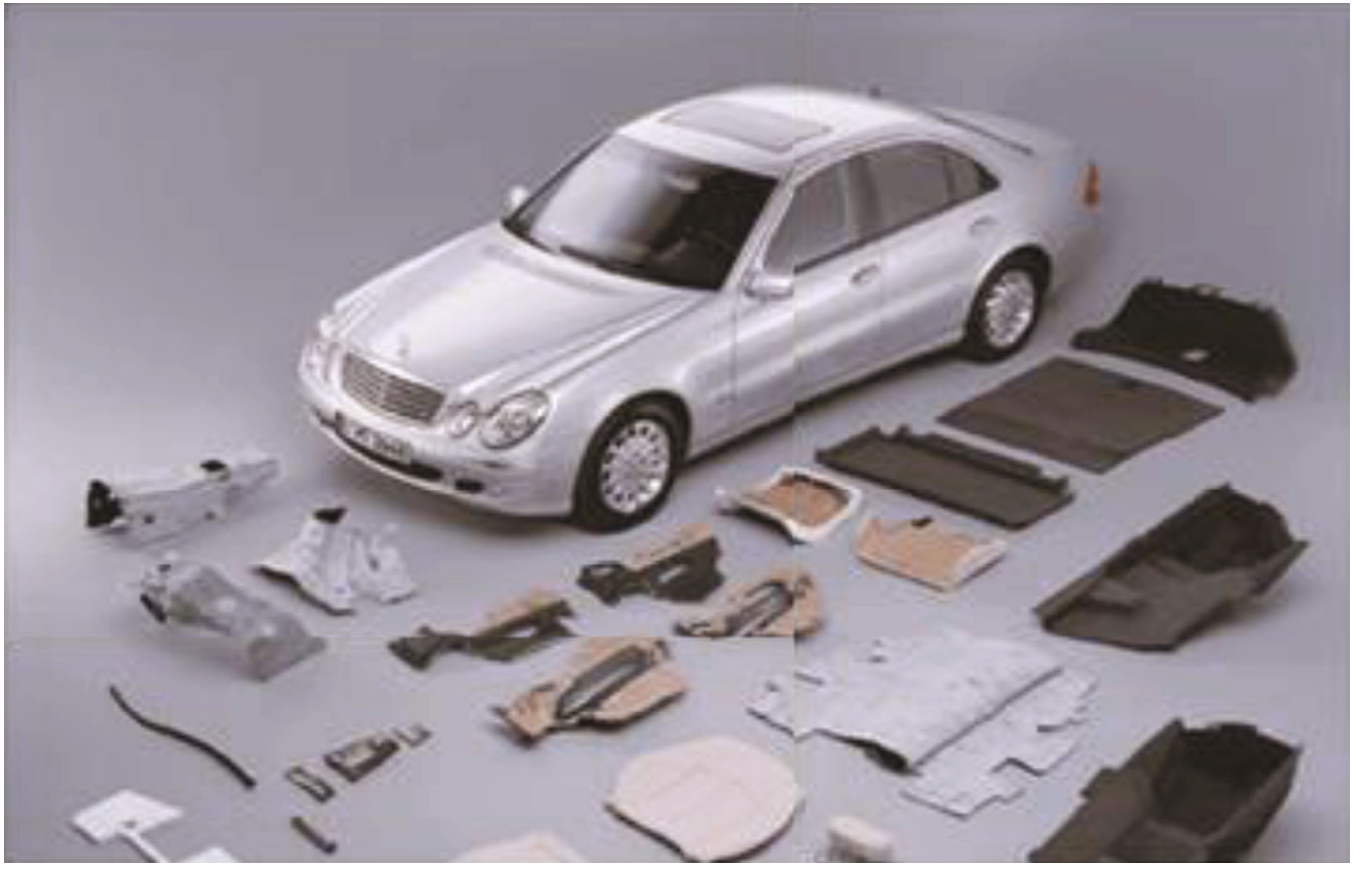

FIGURE 1: A vehicle showing numerous parts produced from PMCs [36].

TABLE 1: Automakers and parts produced from polymer matrix composites [36].

\begin{tabular}{|c|c|c|}
\hline Automakers & Models & Parts \\
\hline Volkswagen & Bora, Golf, Passat Variant & Seatback, door panel, boot liner, boot-lid finish panel \\
\hline BMW & $3,5,7$ series & Door lining panel, seatback, boot lining \\
\hline Opel & Vectra, Zafira, Astra & Door panel, headliner panel, instrument panel \\
\hline Fiat & Marea, Brava, Punto & Boot liner, door panel \\
\hline Audi & $\mathrm{A} 2, \mathrm{~A} 3, \mathrm{~A} 4, \mathrm{~A} 6, \mathrm{~A} 8$ & Spare tire lining, door panel, hat rack, boot lining, seatback \\
\hline $\begin{array}{l}\text { Mercedes } \\
\text { Benz }\end{array}$ & A-class, E-class, S-class & $\begin{array}{c}\text { Seatback, door panel, cover panel, dashboard, windshield, engine cover, roof cover, } \\
\text { instrument panel, bumper }\end{array}$ \\
\hline Toyota & ES3, Brevis, Celsior, Raum & Spare tire lining, seatback, floor mat, door panel \\
\hline Volvo & V70, C70 & Natural foam, seat padding \\
\hline Mitsubishi & Outlander and Eclipse cross & The instrument panel, cargo area floor, door panel \\
\hline $\begin{array}{l}\text { Daimler } \\
\text { Chrysler }\end{array}$ & $\mathrm{A}, \mathrm{C}, \mathrm{E}$, and S class & Door panels, car windshield, dashboard, and pillar cover panel \\
\hline $\begin{array}{l}\text { General } \\
\text { Motors }\end{array}$ & $\begin{array}{l}\text { Cadilac De Ville, Chevrolet } \\
\text { Trial Blazer }\end{array}$ & Seatbacks, cargo area floor mat \\
\hline Peugeot & 406 & Front and rear door panels, seatbacks, and parcel shelves \\
\hline Ford & Mondeo CD 162, Focus & Door panels, boot-liner, door inserts, and floor trays \\
\hline Renault & Twingo and Clio & Rear parcel shelf \\
\hline
\end{tabular}

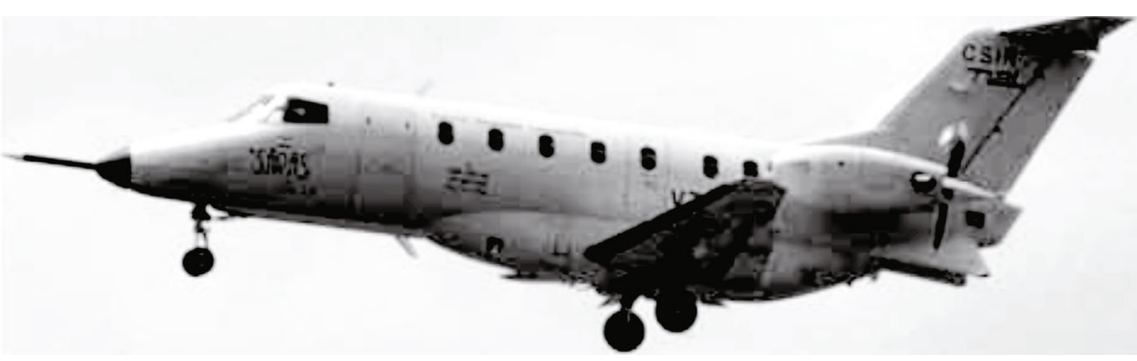

Figure 2: The SARAS 14-seater aircraft [37]. 
$33.5 \mathrm{~kg}$ while that of PMCs was $25.2 \mathrm{~kg}$. The PMCs also had a single body part and no fastener present as against the 31 different parts with a total of 3400 fasteners obtained from using the metal alloys [37, 41].

\section{Biomedical Application}

The medical field is recognized as the leading industry with the most recent advances in the use of polymer composite materials. The use of these materials for biomedical applications is a result of their outstanding properties which include compatible mechanical strength, biodegradability, precise control, biocompatibility, biomimicry, compactness, and bioresorbability among others. Biopolymer materials can smartly imitate the morphological characteristics of living materials due to their biocompatibility. Their areas of application include but are not limited to wound dressing, medical devices, tissue engineering, dental usage, oral tissues, protein immobilization, drug delivery, regenerative medicine, bones and ligament application, blood vessels, antimicrobial materials, and surgical implants [42]. The biomedical field utilizes natural polymers such as chitosan, collagen, guar gum, alginates, agar, pectin, psyllium, pullulan, starch, and cellulose as well as synthetic polymers like polyamide (PA), polyglycolic acid (PGA), polylactic acid (PLA), polycaprolactone (PCL), polylactic-co-glycolic acid (PLGA), and polyesteramides (PEA) while also using fibers as its major form of reinforcement [42-47]. More detailed use of polymer composites for biomedical applications is presented in a broad term as hard (bone) and soft (skin) tissues.

4.1. Bones. The bone is a morphological component that can adapt and remodel itself to fit into any mechanical surroundings it finds itself. It is made up of hydroxyapatite (HA) nanocrystals, bone cells, muccopolysaccharides, collagen fibers, and blood vessels. Hydroxyapatites are continuously used for grafts and bone fillers and can easily be obtained from the waste bones of animals [48]. Their continuous usage is inclusive of their osteoconductivity property which enables the quick development of osteoprogenitor cells. Hence, they serve as bone fillers to aid bone fracture repair which is one of the most sensitive disorders common to bones. Both natural and synthetic degradable polymer composites are extensively used as scaffolds for bone repair due to their excellent mechanical and biological properties [42]. Having established the use of these materials as biomedical materials, sustainability and environmental impact were also considered, and hence, environmentally sustainable processes for the synthesis of HA have been developed and used for the production of hydroxyapatite powders (HAp) [49, 50]. Currently, HAps are being synthesized from both plants and animals using all the existing manufacturing processes [51].

From the investigation of Akagi and his coworkers who compared the effectiveness of HA/PDLLA and b-TCP scaffolds used for bone implant and repair, they were able to conclude from the result obtained that HA/PDLLA composite scaffolds, when used for bone implants, produce better bone repair because of their new bone formation process, biodegradability, minimal risk of residual scaffold left with the composite as against b-TCP scaffold, and their improved cell infiltration shown by immunohistochemistry staining. This result was obtained from the surgical operation carried out on the right and left limbs of the dogs in which a section of their tibial bone was replaced with the HA/PDLLA and bTCP scaffolds. The HA/PDLLA and b-TCP scaffolds were implanted into the right and left limbs, respectively, shown in Figure 3 [52].

4.2. Skin. The skin is the first immune system organ of the body as well as one of the most important parts of the body. This arms it with the responsibility of preventing pathogens and antigens from getting into the body. Nevertheless, they are still exposed to severe conditions such as skin infections, burns, and necrosis. Hence, skin regeneration using biodegradable and biocompatible polymer composites is of great interest to researchers. Also, since polymeric materials have been researched to be very suitable for drug delivery systems, they are extensively used as drug delivery materials. For instance, polymer-based hydrogels are used as carriers for drug molecules such as anticancer, antibiotic, and antifungal drugs. Also, polymeric materials are used for wound dressings to provide a shield to wound sites and to help quicken the healing process as well as for tissue engineering to help reproduce lost or damaged tissues by facilitating the development of new cells [53]. Table 2 presents some of the different polymer-based composites used for biomedical applications [42].

\section{Civil Application}

Over the past few decades, the construction industry has sought new materials and design processes to enhance the structural, mechanical, and environmental performance of buildings and bridge constructions around the world. The traditional materials, steel, concrete, and cement have been serving long enough but not adequate in meeting certain mechanical and environmental requirements, hence creating the need to research new materials that could provide such requirements [54]. Concrete and cement which are most generally used as construction and building materials, respectively, have posed various limitations to the development of novel structures globally, while steel has also been disappointed under certain conditions. Some of the shortcomings of these conventional materials are that cement production gives rise to serious environmental concerns as one tonne of cement production generates about one ton of carbon dioxide and also deteriorates quickly at the outer surface when exposed to alkaline or acid environment [55]. Furthermore, cement concrete exhibits high porosity, cavitation, low flexural strength, low abrasive resistance, low tensile strength, longer setting time, low durability, etc. When infrastructures are left unattended over a long period, these setbacks become overwhelming in the face of different kinds of degradation [54]. Some of the causes of structural degradations are environmental exposure, substandard materials usage, poor design, poor quality construction, etc $[56,57]$.

In the modern days, fiber-reinforced polymer composites (FRPC) have been researched to be excellent material 


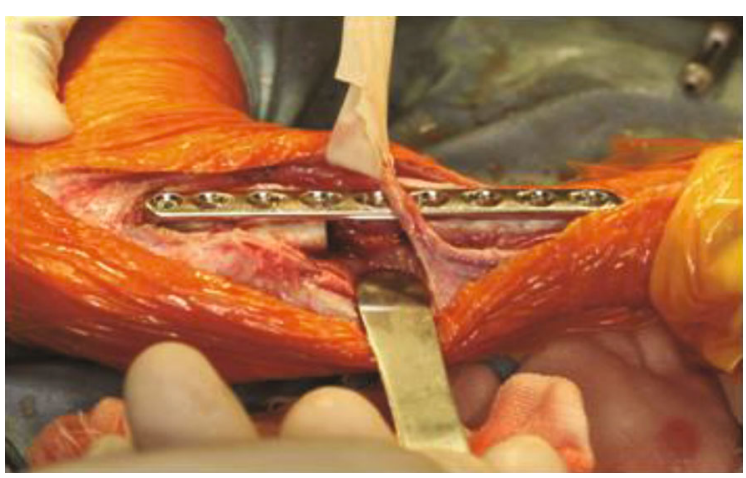

(a)

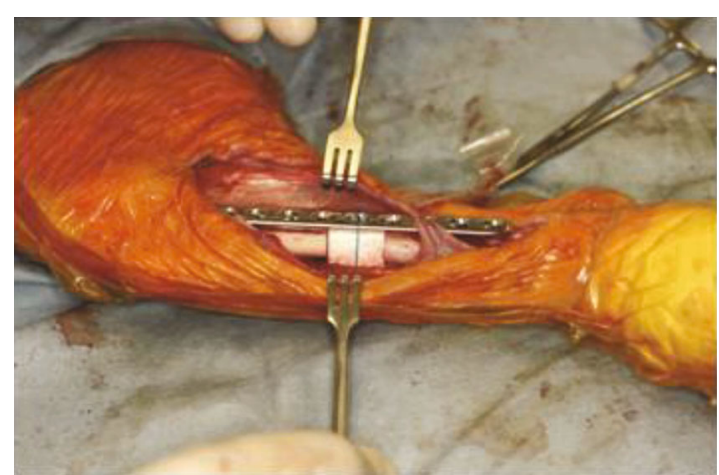

(b)

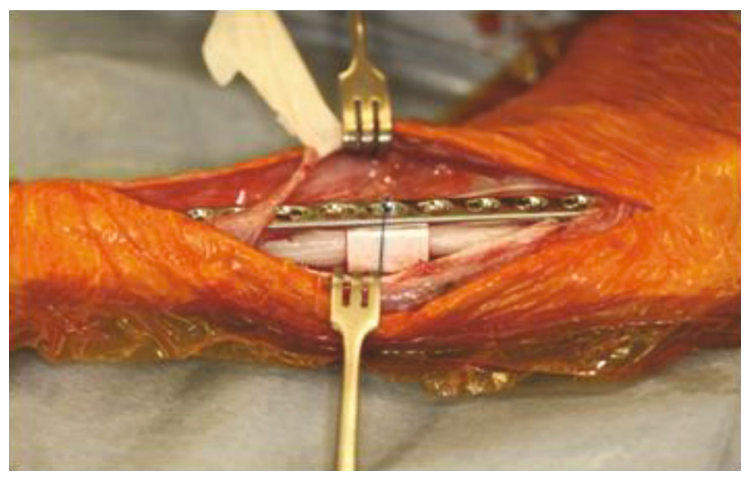

(c)

Figure 3: Images of surgical operation. (a) The central region of the tibia was removed using an oscillating bone saw (black arrow). (b) The HA/PDLLA composite was inserted into the space created (white arrow). (c) The b-TCP composite was inserted into the space created (black arrow) [52].

TABle 2: Polymer composites for biomedical applications [42].

\begin{tabular}{ll}
\hline Polymer composites & Biomedical application \\
\hline Modified HA/chondroitin sulfate & Skin \\
Glycoaminoglycoside/collagen & Bone \\
AL/ibuprofen & Polypropylene carbonate (PPC) \\
Silk fibroin (SF)/ alginate (AL)/HA & Wound dressing \\
Poly(lactide-co-glycolide) (PLAGA)/calcium phosphate & WA/ethylcellulose(EC)/ hydroxyapatite (HA) \\
\hline PCL/bioactive glass (BG) nanoparticles & Kaolin/polyurethane \\
Nanocellulose/poly(vinyl pyrrolidone) (PVP)/ & Oral tissues \\
SF/graphene oxide (GO) & \\
Banana peel powder/CS & Blood vessels \\
Polyglycolic acid (PGA) & \\
Poly(lactic-co-glycolic acid) (PLGA) & \\
\hline Chitosan & \\
PCL/gelatin &
\end{tabular}


substitute for numerous civil engineering applications due to their unique properties which include high strength, lightweight, resistance to corrosion, improved ductility, workability, reduced cost, and improved aesthetic provision. As against the common construction materials, FRPCs help to provide increased strength-to-weight ratio and increased stiffness-to-weight ratio [54]. For example, polymer concrete can be used to replace cement concrete considering its increased strength, good resistance to corrosion, abrasion, and chemicals, improved ductility, high durability, low permeability, decreased maintenance requirement, low cure shrinkage, good adhesive property, eco-friendly characteristic, higher vibration damping property, excellent weathering property, and thawing and freezing resistance. These properties make polymer concrete highly suitable for a variety of civil engineering applications ranging from underground construction, bridge deck, building cladding, floor drains, sewer pipes, utility box, filtration slabs for drinking water, precast product, manholes, industrialized flooring, floor drains, hydraulic structures, for repair and maintenance purposes, for precast and cast purposes, trench lines, geothermal energy process, acid tanks, airport runway, etc. Also, it is noteworthy to mention that in the development of polymer concrete, epoxy resin is mostly used as the binder while a broader choice of materials is used as fillers. They include palm oil fuel ash, PET fibers, silica fume, bagasse ash, fly ash, marble waste, calcium carbonate, etc [55].

Advanced composite materials are of key essence to the construction industry. To prevent corrosion which is a major cause of concrete degradation, FRPC sheets are used to control the effect of corrosion, improve the structural strength, and repair concrete columns by wrapping them with the sheets. The concrete columns also experience increased energy absorption, shear capacity, load-carrying capacity, and damage control. They are also used for strengthening highway structures, beams, bridge structures, slabs, railway structures, walls, and beam-column joints [57, 58]. Swamy et al. [59] further explain the advantages of substituting steel plates for FRPC plates for reinforced concrete beams.

\section{Marine Application}

In more recent decades, the marine industry has experienced an extensive usage of advanced composites due to the excellent engineering properties that they offer. Weight and cost savings as well as environmental sustainability are the major drivers that have led to an increase in the use of these materials for various marine sectors $[60,61]$. The use of conventional materials and some advanced composites all through various marine sectors has progressively led to an outcry on the environmental impacts caused by these materials which is facilitated much more by the aggressive environments they find operation in such as saltwater. The increasing concern for promoting a sustainable environment has led to the legislation of stricter manufacturing and maintenance policies by various regulatory bodies [61]. This has forced manufacturers to employ new innovative materials and processes while also understanding the life cycle of their products in a bid to simultaneously develop high engineering performance components and ensure an eco-friendly environment. These demands have progressively required the incorporation of biodegradable polymer matrix composites (eco-composites) as they aid material recycling, the reduction of toxic and hazardous materials, waste, and polluting air emissions while offering outstanding mechanical properties $[7,25,61,62]$.

One such material classification is the fiber-reinforced polymer composite (FRPC) materials which can efficiently use a biosourced thermoplastic such as polylactic acid (PLA) or other thermoplastics such as polyamide or polypropylene. Presently, there is a need for a further shift to this choice of materials from epoxy and vinyl ester resins with carbon, glass, and aramid reinforcements [60, 63, 64]. However, these materials have still been experimented to be of better service than the traditional materials due to deterioration. According to Mouritz et al. [65], studies were carried out to compare the cost, weight, and structural performance of large patrol boats made using steel, aluminum, or sandwich. The studies found that the structural weight of a patrol boat made of glass-reinforced plastic (GRP) sandwich composite material should be $10 \%$ lighter than an aluminum boat and $36 \%$ lighter than a steel boat of similar size. Also, the use of hybrid composites such as hybrid glass-carbon reinforced polymer composite (GCG2C)s best helps to retain over a long period, the mechanical properties needed by materials for efficient performance in the marine industry. Hybrid (GCG2C)s possesses a very high flexural strength of $462 \mathrm{MPa}$ with the lowest water absorption tendency. Likewise, hybridized flax and carbon fiber composite can be used to replace aluminum 6061 for structural materials as it offers about $141 \%$ improvement in vibration damping properties, $252 \%$ improvement in tensile strength with $49 \%$ reduction in weight. The use of jute and carbon fibers as reinforcements for hybridized composite structures also help to improve vibration-damping properties and economic and environmental sustainability [14].

Some of the outstanding properties of advanced composite materials promoting their usage in the marine industry are good strength-to-weight and stiffness-to-weight ratios, high durability, increased dimensional stability, increased range, flatness for stealth requirements, design flexibility, reduced fuel consumption, manufacturing and maintenance costs, lower electrical and magnetic signatures, increased speed, reduced wear, low moisture absorption, corrosion, impact, and resistances, increased vibration damping characteristics, sound barring, resistance to aggressive seawater, improved efficiency, high load-bearing capacity, lower inertia, increased buoyancy, and high level of acoustic transparency $[14,63,65]$, [66]. Therefore, because of these excellent properties, marine sectors such as the boat and ship construction sector, renewable energy sector, offshore structural sector, and repairing sector [66] largely use them for fittings and internal equipment such as valves, ducts, pumps, heat exchangers, pipes, naval vessels, boats, small ships, superstructures, masts, decks, bulkheads, machinery, propellers, rudders, propulsion shafts, for warship equipment like destroyers, frigates, for fittings, hovercraft, corvettes, torpedo tubes, antenna trunks, engine components, tanks (water, fuel, lube oil), ferries, rotor blades, for gas pipelines, for hulls, for 
pillars, for floating platforms such as tendons, risers, and support structures, for sailboats, yachts, and barges, topside structures, railings, radomes, tidal and wind turbine blades, and sonar domes $[14,61,65,66]$.

\section{Military Application}

The military industry is considered to be a big fan of nanotechnology for application in weaponry, communication, and protection. Over the years, staggering growth in the use of nanomaterials has been witnessed in the defense and military space in a bid to significantly improve the performance of military devices as well as increasing personnel comfort and survivability chances. Figure 4 shows the various nanomaterials used in defense and military sectors. Polymer nanocomposites (PNCs) have experienced a tremendous rise in their use in various military and defense sectors such as sensing, military medicine, smart structures and textiles, power generation and management, military weapons, and aerodynamics. PNC is a class of polymer composites having its polymer matrix reinforced with particles at the nanoscale (nanoparticles) thereby possessing excellently improved fatigue and fracture resistance. PNCs are used for producing military devices, materials, and structures that are lighter, smaller, cheaper, more accurate, smarter, and stronger [67, 68].

This industry is largely connected to the transportation industry in general. They are inseparable because the military and defense fields continuously and unavoidably make use of vehicles, aircraft, ships, and drones for their effective operations. This gives rise to the need for specific requirements such as fire-retardation, shock absorption, electromagnetic shielding, sensors, high-temperature resistance, vehicle liners for protection, actuators, ballistic performance, electrical energy storage (capacitors), and microwave absorption, in military vehicles, ships, and aircraft as they are being used for special purposes compared to civilian ones [69]. In military ships, for example, a ship production company, Ingall's Shipbuilding, achieves some of these requirements by making use of carbon-reinforced vinyl ester resin and phenolic fiberglass laminate panels to completely build the deckhouse and roof, respectively. In other ship parts, polymer composites are used for making the antennas, masts, and transparent radars. Likewise, the Lockheed Martin F-35 Lightning fighter aircraft has parts like the fuselage, wings, horizontal, and vertical stabilizers to be made of carbon fiber-reinforced polymer (CFRP) composites to make for extra toughness and durability [37].

In the area of soldiers' protection, PNCs are efficiently used for making body armor, smart textiles, gloves, and boots. Polymer matrix when reinforced with nanomaterials like Kevlar and graphene help to produce exceptionally strong, smart, and lightweight high-technology battle suits. When shear thickening fluids (a fluid containing a dispersion of nanoparticles) such as silica nanoparticles in polyethylene glycol are further applied, they will lead to the production of more flexible, dense, and stronger body armors. These body armors aid flexible movements of the wearer, protect the body against chemicals and toxins, and resist the impact of high-speed bullets as well as protection against blunt weapons like bars, stones, and sticks [67-69]. Figure 5 shows a typical example in Russia's recent battle suit made of PNCs. The "Star Wars" high-tech armor capitalizes on the unique properties of graphene nanofiller which possesses excellent strength (it is 100 times stronger than steel), lightweight, high hydrophobicity capacity, high stamina, excellent electrical and thermal conductivity, and ballistic capacity. The armor consists of a tinted night vision helmet, radio cable, exoskeleton layer, gloves, padded khaki, and firearm [67]. More on the benefits of graphene, nanofillers in polymer composites for military applications are extensively covered by some previous researchers [70-76].

\section{Future Trends}

It is evident that the application of polymer matrix composites is now dominant across various industries and sectors as they significantly help to improve the performance and efficiency of materials across these diverse fields due to their outstanding properties. Presently, polymer-based composites are being used in every area of human activities without exception, some of which are in transportation [14,37], civil construction $[77,78]$, biomedical $[45]$, military [67, 69], sport and leisure [79, 80], food and packaging [81-83], and electrical and electronics $[84,85]$. Therefore, there are needs to look into the advancement of these materials in the future to consider what the future has to offer. How can polymer solve future challenges among competing for future materials? Nanotechnology has been identified as one of the ways forward in which by combining the benefits in nanotechnology with the advantages in polymer-based materials, more advanced and dynamic materials will be achieved. Going by the present events, it was assumed that future trends in the use of PCMs will depend ultimately on the use of nanomaterials as reinforcements to meet the ever-evolving and dynamic requirements of different fields. This assumption was based on the premise that nanofillers greatly aid good interaction between the polymer matrix and the reinforcement that usually resulted in outstanding material properties. The sole incorporation of nanotechnology for the production of these advanced composites will provide the materials with further improved properties required for ever-increasing properties needed for satisfactory performance. The communication, electronics, energy, household, packaging, sports, and leisure industries are not left out in the application of polymer nanocomposites as they are also already fully involved in the use of advanced composites for various applications. For example, in the sport and leisure industry, an Australian surfboard manufacturing company, Samsara Surfboards is producing sustainable and eco-friendly surfboards of ultrahigh performance. The surfboard is made of commingled flax/PP, commingled flax/PLA, and flax fibers thereby making it to be highly environmentally friendly throughout its lifecycle. Also, the German company AX-Lightness $\mathrm{GmbH}$, who is the major supplier of the Formula One sector with polymer composite materials, produced high-tech mountain bikes with wheels from epoxy prepregs and woven carbon fiber as polymer matrix and reinforcement, respectively [37]. In 


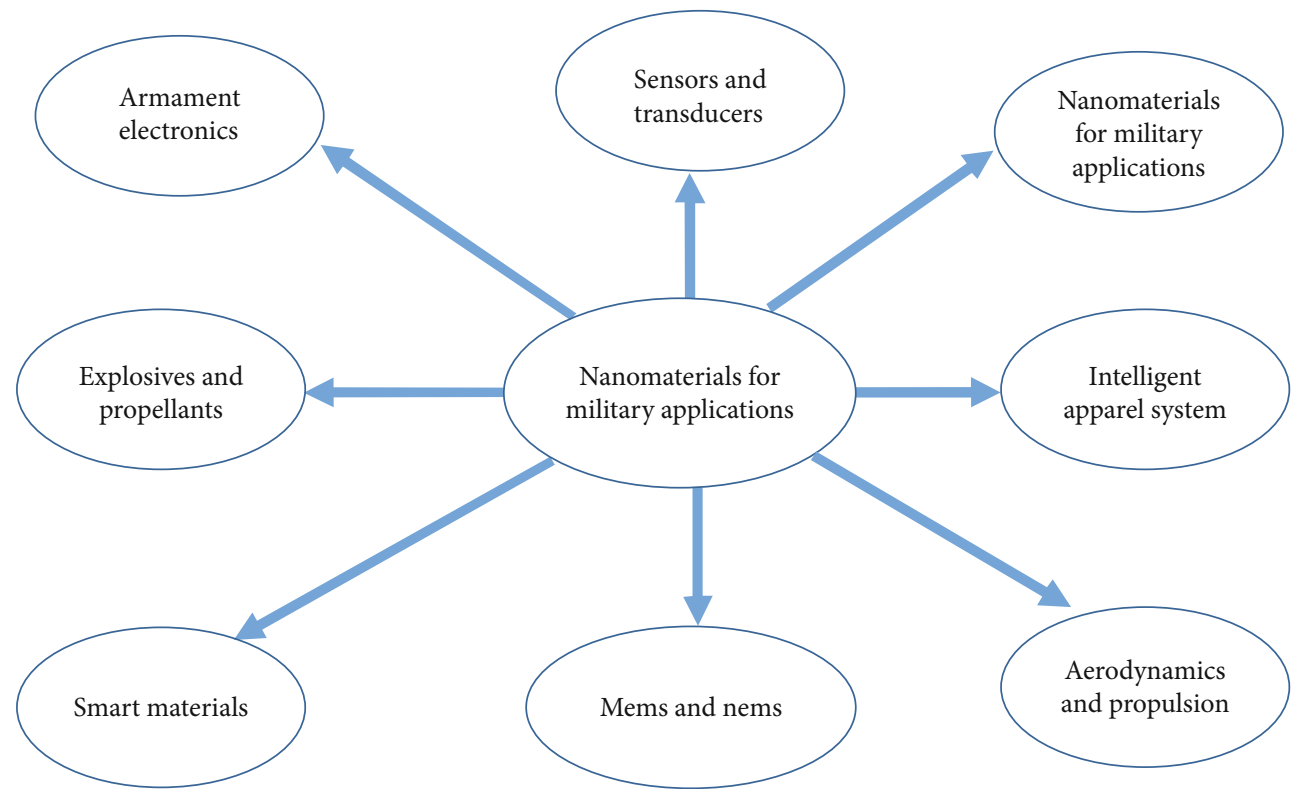

FIgURE 4: Various nanomaterials used in defense and military sectors [67].
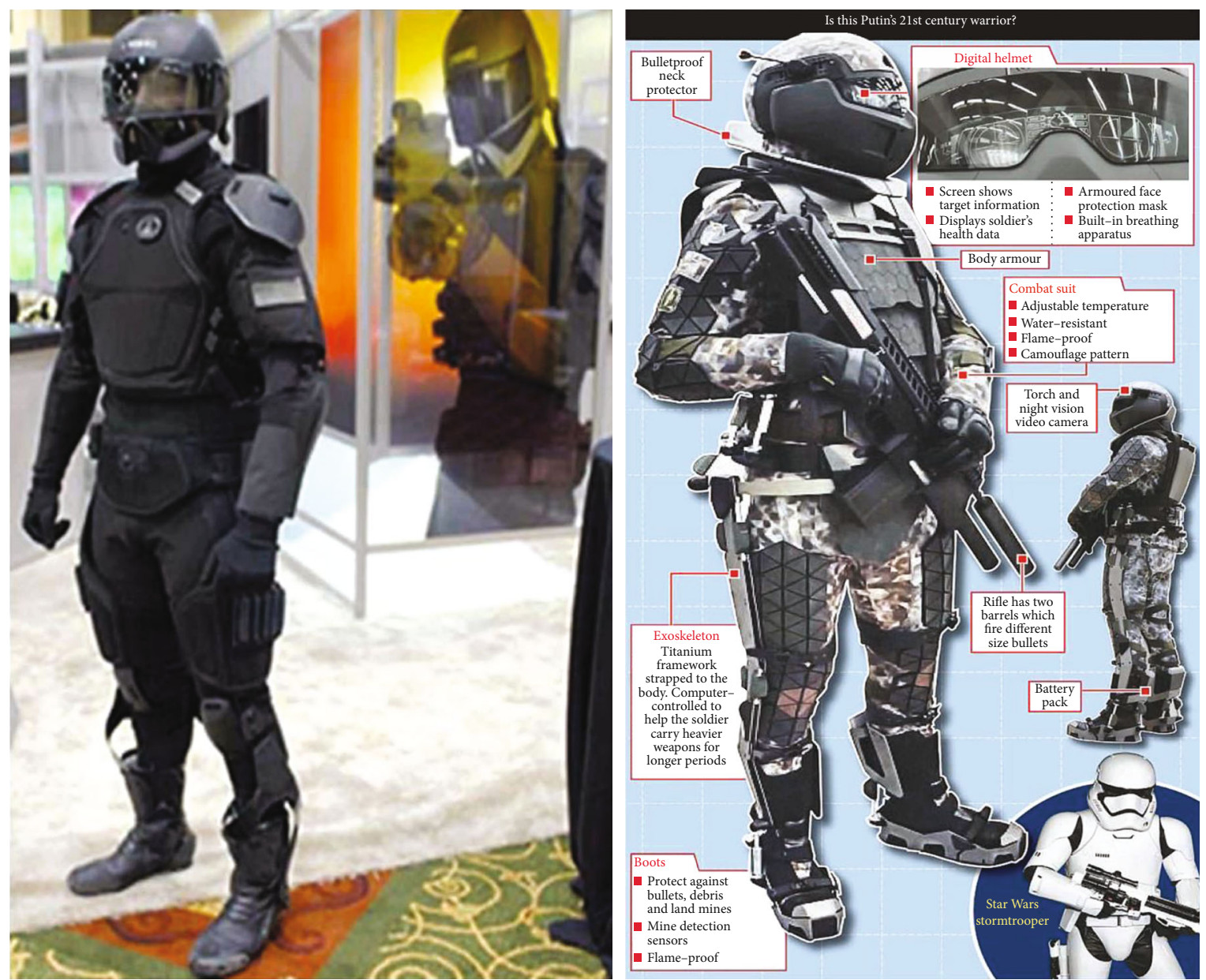

FiguRE 5: Russian advanced high-tech amour item that includes an exoskeleton or the outer layer, designed to boost strength and stamina [67]. 
the area of electrical and electronics, PNCs can be used for making switchgear, panels, connectors, insulators, capacitor covers, headphone covers, and Li-ion battery covers [3].

\section{Conclusion}

Knowledge and information are powerful weapons that have been changing the course of mankind in the areas of science and engineering. These have been effectively communicated through research and developments that are readily available for readers to consider for application. This review has provided more information regarding the various areas of applications and challenges with polymer-based composites. The work revealed the prospect in polymer matrix composites as indispensable materials for the future whereby only modifications and adaptations will be the trends in the use of polymer-based composite materials. Hence, more research to overcome the present challenges in the areas of applications and environmental impact needs to be intensified.

\section{Data Availability}

The data used to support the findings of this study are included within the article.

\section{Conflicts of Interest}

The authors declare that they have no conflicts of interest.

\section{Acknowledgments}

The authors wish to acknowledge Landmark University Centre for Research, Innovation, and Development (LUCRID) through the SDGs 9 Group: Industry, Innovation, and Infrastructures for their support.

\section{References}

[1] The Seven Ages of Materials E\&T Magazine, Engineering \& Technology, 2019, July 2020, https://eandt.theiet.org/content/ articles/2019/09/the-seven-ages-of-materials/.

[2] R.-M. Wang, S.-R. Zheng, and Y.-P. Zheng, "Introduction to polymer matrix composites," in Polymer Matrix Composites and Technology, pp. 1-548, Woodhead Publishing, 2011.

[3] "Polymer matrix composites: properties and applications matmatch," August 2020, https://matmatch.com/learn/ material/polymer-matrix-composites.

[4] V. V. Kumar, G. Balaganesan, J. K. Y. Lee, R. E. Neisiany, S. Surendran, and S. Ramakrishna, "A review of recent advances in nanoengineered polymer composites," Polymers, vol. 11, no. 4, p. 644, 2019.

[5] F. L. Matthews and R. D. Rawlings, "Polymer-matrix composites," in Composite Materials, pp. 168-205, Woodhead Publishing, 1999.

[6] "Polymer matrix composites applications in many industries," August 2020, https://www.polymerexpert.biz/industries/173composites.

[7] G. Neşer, "Polymer based composites in marine use: history and future trends," Procedia Engineering, vol. 194, pp. 19-24, 2017.
[8] J. S. Binoj, R. E. Raj, S. A. Hassan, M. Mariatti, S. Siengchin, and M. R. Sanjay, "Characterization of discarded fruit waste as substitute for harmful synthetic fiber-reinforced polymer composites," Journal of Materials Science, vol. 55, no. 20, pp. 8513-8525, 2020.

[9] S. Vigneshwaran, R. Sundarakannan, K. M. John et al., "Recent advancement in the natural fiber polymer composites: a comprehensive review," Journal of Cleaner Production, vol. 277, article 124109, 2020.

[10] Q. T. H. Shubhra, A. K. M. M. Alam, M. A. Gafur et al., "Characterization of plant and animal based natural fibers reinforced polypropylene composites and their comparative study," Fibers and Polymers, vol. 11, no. 5, pp. 725-731, 2010.

[11] T. G. Yashas Gowda, M. R. Sanjay, K. Subrahmanya Bhat, P. Madhu, P. Senthamaraikannan, and B. Yogesha, "Polymer matrix-natural fiber composites: an overview," Cogent Engineering, vol. 5, no. 1, 2018.

[12] E. Reashad, B. Kabir, and E. N. Ferdous, "Kevlar-the super tough fiber," International Journal of Textile Science, vol. 1, no. 6, pp. 78-83, 2012.

[13] S. Feroz, N. Muhammad, J. Ratnayake, and G. Dias, "Keratin based materials for biomedical applications," Bioactive Materials, vol. 5, no. 3, pp. 496-509, 2020.

[14] D. Rajak, D. Pagar, P. Menezes, and E. Linul, "Fiber-reinforced polymer composites: manufacturing, properties, and applications," Polymers, vol. 11, no. 10, p. 1667, 2019.

[15] K. Prabhakar, S. Debnath, R. Ganesan, and K. Palanikumar, "A review of mechanical and tribological behaviour of polymer composite materials," IOP Conference Series: Materials Science and Engineerin, vol. 344, no. 1, article 012015, 2018.

[16] K. Friedrich, "Polymer composites for tribological applications," Advanced Industrial and Engineering Polymer Research, vol. 1, no. 1, pp. 3-39, 2018.

[17] A. Ali and A. Andriyana, "Properties of multifunctional composite materials based on nanomaterials: a review," RSC Advances, vol. 10, no. 28, pp. 16390-16403, 2020.

[18] A. S. Singha and V. K. Thakur, "Synthesis, characterisation and analysis of hibiscus sabdariffa fibre reinforced polymer matrix based composites," Polymers and Polymer Composites, vol. 17, no. 3, pp. 189-194, 2018.

[19] R. Arjmandi, A. Hassan, K. Majeed, and Z. Zakaria, "Rice husk filled polymer composites," International Journal of Polymer Science, vol. 2015, Article ID 501471, 32 pages, 2015.

[20] V. K. Thakur, A. S. Singha, and M. K. Thakur, "Biopolymers based green composites: mechanical, thermal and physicochemical characterization," Journal of Polymers and the Environment, vol. 20, no. 2, pp. 412-421, 2012.

[21] S. Das Lala, A. B. Deoghare, and S. Chatterjee, "Effect of reinforcements on polymer matrix bio-composites - an overview," IEEE Journal of Selected Topics in Quantum Electronics, vol. 25, no. 6, pp. 1039-1058, 2018.

[22] F. J. Khusiafan, "Use of KEVLAR ${ }^{\circledR} 49$ in aircraft components," Engineering Management Research, vol. 7, no. 2, pp. 14-19, 2018.

[23] T. J. Singh and S. Samanta, "Characterization of Kevlar fiber and its composites: a review," Materials Today: Proceedings, vol. 2, no. 4-5, pp. 1381-1387, 2015.

[24] R. Karthikeyan and B. Srinivasan, "Industrial applications of keratins - a review," Journal of Scientific and Industrial Research, vol. 66, pp. 710-715, 2014.

[25] I. O. Oladele, A. A. Adediran, A. D. Akinwekomi, M. H. Adegun, O. O. Olumakinde, and O. O. Daramola, "Development 
of ecofriendly snail shell particulate-reinforced recycled waste plastic composites for automobile application," The Scientific World Journal, vol. 2020, Article ID 7462758, 8 pages, 2020.

[26] OECD, "Material resources, productivity and the environment: key findings material resources, productivity and the environment key findings," 2007, https://www.oecd.org/ environment/waste/material-resources-productivity-and-theenvironment-9789264190504-en.htm.

[27] J. M. Allwood, M. F. Ashby, T. G. Gutowski, and E. Worrell, "Material efficiency: providing material services with less material production," Philosophical Transactions of the Royal Society A - Mathematical Physical and Engineering Sciences, vol. 371, no. 1986, article 20120496, 2013.

[28] A. F. Owa, I. O. Oladele, A. A. Adediran, and J. A. Omotoyinbo, "Development of new polymers from Thevetia peruviana oil," International Journal of Engineering Research in Africa, vol. 48, pp. 9-23, 2020.

[29] I. O. Oladele, A. D. Akinwekomi, O. G. Agbabiaka, and M. O. Oladejo, "Influence of biodegradation on the tensile and wear resistance properties of bio-derived $\mathrm{CaCO}_{3}$ /epoxy composites," Journal of Polymer Research, vol. 26, no. 1, p. 16, 2019.

[30] I. O. Oladele, I. O. Ibrahim, A. A. Adediran, A. D. Akinwekomi, Y. V. Adetula, and T. M. A. Olayanju, "Modified palm kernel shell fiber/particulate cassava peel hybrid reinforced epoxy composites," Results Mater, vol. 5, article 100053, 2020.

[31] O. G. Agbabiaka, I. O. Oladele, A. D. Akinwekomi et al., "Effect of calcination temperature on hydroxyapatite developed from waste poultry eggshell," Scientific African, vol. 8, article e00452, 2020.

[32] O. O. Daramola, J. L. Olajide, I. O. Oladele et al., "Mechanical and wear behaviour of polylactic acid matrix composites reinforced with crab-shell synthesized chitosan microparticles," Materials Today: Proceedings, 2020, In press.

[33] A. Pilipović, P. Ilinčić, J. Petruša, and Z. Domitran, "Influence of polymer composites and memory foam on energy absorption in vehicle application," Polymers, vol. 12, no. 6, p. 1222, 2020.

[34] M. N. Suddin, M. S. Salit, N. Ismail, M. A. Maleque, and S. Zainuddin, "Total design of polymer composite automotive bumper fascia," Suranaree Journal of Science and Technology, vol. 12, pp. 39-45, 2004.

[35] B. Ravishankar, S. K. Nayak, and M. A. Kader, "Hybrid composites for automotive applications - a review," Journal of Reinforced Plastics and Composites, vol. 38, no. 18, pp. 835$845,2019$.

[36] L. Mohammed, M. N. M. Ansari, G. Pua, M. Jawaid, and M. S. Islam, "A review on natural fiber reinforced polymer composite and its applications," International Journal of Polymer Science, vol. 2015, Article ID 243947, 15 pages, 2015.

[37] A. G. Koniuszewska and J. W. Kaczmar, "Application of polymer based composite materials in transportation," Progress in Rubber Plastics and Recycling Technology, vol. 32, no. 1, pp. 1-24, 2018.

[38] S. Nambiar and J. T. W. Yeow, "Polymer-composite materials for radiation protection," ACS Applied Materials \& Interfaces, vol. 4, no. 11, pp. 5717-5726, 2012.

[39] R. Yadav, M. Tirumali, X. Wang, M. Naebe, and B. Kandasubramanian, "Polymer composite for antistatic application in aerospace," Defence Technology, vol. 16, no. 1, pp. 107-118, 2020.

[40] C. Soutis and P. Irving, Polymer Composites in the Aerospace Industry, pp. 1-18, Woodhead Publishing, 2015.
[41] C. Soutis, "Fibre reinforced composites in aircraft construction," Progress in Aerospace Science, vol. 41, no. 2, pp. 143151, 2005.

[42] M. Zagho, E. Hussein, and A. Elzatahry, "Recent overviews in functional polymer composites for biomedical applications," Polymers, vol. 10, no. 7, p. 739, 2018.

[43] J. Yunas, B. Mulyanti, I. Hamidah et al., "Polymer-based MEMS electromagnetic actuator for biomedical application : a review," Polymers, vol. 12, no. 5, p. 1184, 2020.

[44] M. A. Ghalia and Y. Dahman, "Chapter 6. Advanced nanobiomaterials in tissue engineering: synthesis, properties, and applications," in Nanobiomaterials in Soft Tissue Engineering, pp. 141-172, Elsevier Inc., 2016.

[45] S. Arumugam, J. Kandasamy, A. U. Md Shah et al., "Investigations on the mechanical properties of glass fiber/sisal fiber/chitosan reinforced hybrid polymer sandwich composite scaffolds for bone fracture fixation applications," Polymers, vol. 12, no. 7, p. 1501, 2020.

[46] "Natural Polymers Polymers Chemistry Source of Polymers Byju's," September 2020, https://byjus.com/chemistry/ natural-polymers/.

[47] P. Srivastava and S. Abul Kalam, "Natural Polymers as Potential Antiaging Constituents," in Pharmacognosy - Medicinal Plants, pp. 1-25, IntechOpen, 2019.

[48] I. O. Oladele and T. A. Adewole, "Influence of cow bone particle size distribution on the mechanical properties of cow bonereinforced polyester composites," Biotechnology Research International, vol. 2013, Article ID 725396, 5 pages, 2013.

[49] I. O. Oladele, O. G. Agbabiaka, A. A. Adediran, A. D. Akinwekomi, and A. O. Balogun, "Structural performance of poultry eggshell derived hydroxyapatite based high density polyethylene bio-composites," Heliyon, vol. 5, no. 10, article e02552, 2019.

[50] N. I. Agbeboh, I. O. Oladele, O. O. Daramola, A. A. Adediran, O. O. Olasukanmi, and M. O. Tanimola, "Environmentally sustainable processes for the synthesis of hydroxyapatite," Heliyon, vol. 6, no. 4, article e03765, 2020.

[51] I. O. Oladele, O. G. Agbabiaka, O. G. Olasunkanmi, A. O. Balogun, and M. O. Popoola, "Non-synthetic sources for the development of hydroxyapatite," Journal of Applied Biotechnology \& Bioengineering, vol. 5, no. 2, pp. 92-99, 2018.

[52] H. Akagi, H. Ochi, S. Soeta et al., "A comparison of the process of remodeling of Hydroxyapatite/Poly-D/L-Lactide and BetaTricalcium phosphate in a loading site," BioMed Research International, vol. 2015, Article ID 730105, 14 pages, 2015.

[53] J. O. Akindoyo, M. D. H. Beg, S. Ghazali, H. P. Heim, and M. Feldmann, "Effects of surface modification on dispersion, mechanical, thermal and dynamic mechanical properties of injection molded PLA-hydroxyapatite composites," Composites Part A: Applied Science and Manufacturing, vol. 103, pp. 96-105, 2017.

[54] A. K. Gand, T. M. Chan, and J. T. Mottram, "Civil and structural engineering applications, recent trends, research and developments on pultruded fiber reinforced polymer closed sections: a review," Frontiers of Structural and Civil Engineering, vol. 7, no. 3, pp. 227-244, 2013.

[55] B. Sarde and Y. D. Patil, "Recent research status on polymer composite used in concrete-an overview," Materials Today: Proceedings, vol. 18, pp. 3780-3790, 2019.

[56] G. Martínez-Barrera, O. Gencel, and J. M. L. Reis, "Civil engineering applications of polymer composites," International 
Journal of Polymer Science, vol. 2016, Article ID 3941504, 2 pages, 2016.

[57] S. S. Pendhari, T. Kant, and Y. M. Desai, "Application of polymer composites in civil construction: a general review," Composite Structures, vol. 84, no. 2, pp. 114-124, 2008.

[58] L. C. Hollaway, "Polymers, fibres, composites and the civil engineering environment: a personal experience," Advances in Structural Engineering, vol. 13, no. 5, pp. 927-960, 2016.

[59] R. N. Swamy, R. Jones, and J. W. Bloxham, "Structural behaviour of reinforced concrete beams strengthened by epoxybonded steel plates," Structural Engineer, vol. 65, no. 2, pp. 59-68, 1987.

[60] P. Davies, "Environmental degradation of composites for marine structures: new materials and new applications," Philosophical Transactions of the Royal Society A - Mathematical Physical and Engineering Sciences, vol. 374, no. 2071, article 20150272, 2016.

[61] J. Dulieu-barton, "Composite materials for marine applications," in Key Challenges for the Future School of Engineering Sciences, R. A. Shenoi, J. M. Dulieu-Barton, S. Quinn, J. I. R. Blake, and S. W. Boyd, Eds., pp. 1-25, University of Southampton, 2011.

[62] E. Pellicer, D. Nikolic, J. Sort et al., Advances in Applications of Industrial Biomaterials, Springer International Publishing, 2017.

[63] M. Muralidhar Singh, K. V. Nagesha, T. M. Gurubasavaraju, H. Kumar, K. M. Ajay, and G. Vijaya, "Evaluation of Mechanical Properties of Polymer Composites Profiles for Marine Applications," Grenze International Journal of Engineering and Technology, pp. 344-347, 2018.

[64] "Composites in the Marine Industry," August 2020, https:// www.azom.com/article.aspx?ArticleID $=8155$.

[65] A. P. Mouritz, E. Gellert, P. Burchill, and K. Challis, "Review of advanced composite structures for naval ships and submarines," Composite Structures, vol. 53, no. 1, pp. 21-42, 2001.

[66] F. Rubino, A. Nisticò, F. Tucci, and P. Carlone, "Marine application of fiber reinforced composites: a review," Journal of Marine Science and Engineering, vol. 8, no. 1, p. 26, 2020.

[67] E. R. Sadiku, O. Agboola, M. J. Mochane et al., "The use of polymer nanocomposites in the aerospace and the military/defence industries," in Polymer Nanocomposites for Advanced Engineering and Military Applications, pp. 316-349, IGI Global, 2019.

[68] E. Edwards, C. Brantley, and P. B. Ruffin, "Overview of nanotechnology in military and aerospace applications," in Nanotechnology Commercialization, pp. 133-176, John Wiley \& Sons, 2017.

[69] R. Kurahatti, A. Surendranathan, S. Kori, N. Singh, A. Kumar, and S. Srivastava, "Defence applications of polymer nanocomposites," Defence Science Journal, vol. 60, no. 5, pp. 551-563, 2010.

[70] J. Njuguna and K. Pielichowski, "Polymer nanocomposites for aerospace applications: fabrication," Advanced Engineering Materials, vol. 6, no. 4, pp. 193-203, 2004.

[71] Q.-Q. Ni, C.-s. Zhang, Y. Fu, G. Dai, and T. Kimura, "Shape memory effect and mechanical properties of carbon nanotube/shape memory polymer nanocomposites," Composite Structures, vol. 81, no. 2, pp. 176-184, 2007.

[72] B. Itapu and A. Jayatissa, "A review in graphene/polymer composites," Chemical Science International Journal, vol. 23, no. 3, pp. 1-16, 2018.
[73] J. Njuguna and K. Pielichowski, "Polymer nanocomposites for aerospace applications: properties," Advanced Engineering Materials, vol. 5, no. 11, pp. 769-778, 2003.

[74] D. Galpaya, Synthesis, Characterization and Applications of Graphene Oxide-Polymer Nanocomposites, [Ph.D thesis], Queensland University of Technology, 2015.

[75] J. Njuguna and K. Pielichowski, "Polymer nanocomposites for aerospace applications: characterization," Advanced Engineering Materials, vol. 6, no. 4, pp. 204-210, 2004.

[76] D. M. Khan, A. Kausar, and S. M. Salman, "Exploitation of nanobifiller in polymer/graphene oxide-carbon nanotube, polymer/graphene oxide-nanodiamond, and polymer/graphene oxide-montmorillonite composite: a review," PolymerPlastics Technology and Engineering, vol. 55, no. 7, pp. 744768, 2015.

[77] M. F. Humphreys, "The use of polymer composites in construction," 2003, https://eprints.qut.edu.au/139/1/ Humphreys-polymercomposites.pdf.

[78] S. M. Halliwell, Polymer Composites, Construction Research Communications Ltd, 2000, https://projects.bre.co.uk/ composites/pdf/BR405_short.pdf.

[79] R. P. Brown, Polymers in Sport and Leisure, Smart Publications, 2001.

[80] L. Zhang, "The application of composite fiber materials in sports equipment," in Proceedings of the 2015 International Conference on Education, Management, Information and Medicine, pp. 450-453, Shenyang, China, 2015.

[81] S. A. Attaran, A. Hassan, and M. U. Wahit, "Materials for food packaging applications based on bio-based polymer nanocomposites," Journal of Thermoplastic Composite Materials, vol. 30, no. 2, pp. 143-173, 2015.

[82] A. Bratovčić, A. Odobašić, S. Ćatić, and I. Šestan, “Application of polymer nanocomposite materials in food packaging," Croatian Journal of Food Science and Technology, vol. 7, no. 2, pp. 86-94, 2015.

[83] S. Sablani, "Polymer nanocomposites for food packaging applications," in Food Nanoscience and Nanotechnology, H. Hernández-Sánchez and G. Gutiérrez-López, Eds., Food Engineering Series. Springer, Cham, Switzerland, 2015.

[84] M. Tyagi and D. Tyagi, "Polymer nanocomposites and their applications in electronics industry," International Journal of Electrical and Electronics Engineering, vol. 7, no. 6, pp. 603608, 2014.

[85] S. Bhadra and P. N. Khanam, "Electrical and electronic application of polymer-carbon composites," in Carbon-Containing Polymer Composites, pp. 397-455, Springer, 2019. 